\title{
6 価クロムフリー表面処理技術
}

\author{
軽 部 健 志*, 迫 良 輔* \\ *日本パーカライジング(株) 総合技術研究所（†254-0012 神奈川県平塚市大神 2784）
}

\section{Surface Treatment Technology of Hexavalent Chrome Free}

\author{
Kenji KARUBE* and Ryosuke SAKO*
}

${ }^{*}$ Central Reseach Laboratories, Nihon Parkerizing Co., Ltd. (2784, Ohgami, Hiratsuka-shi, Kanagawa 254-0012)

Key Words : Hexavalent Chrome Free, Surface Treatment, Conversrion Coating, Aluminum Alloy, Galvanized Steel

\section{1.はじめに}

金属は我々の生活において必要不可欠な材料であるが，耐 食性・意匠性などの点から, 何らかの表面処理が施されて使 用されるのが一般的である。そのため, 金属には極めて多く の表面処理方法が存在するが，その中でもクロメート処理は， 自動車など車両部品, 家電製品本体および部品などに使用さ れるアルミニウム合金材および亜鉛めっき材を中心に，幅広 く使用されている。このことは，クロメート処理が良好な耐 食性や塗装密着性を兼ね備え, かつ, それを安価に実現させ るという点で, 極めてコストパフォーマンスの高い表面処理 方法であることの証明に他ならない。

しかしながら，その一方で，クロメート処理の皮膜または 処理液は, 通常 6 価クロムを含有しており, 日本産業衛生学 会においても，6価クロムは作業環境濃度で $0.05 \mathrm{mg} / \mathrm{m}^{3}$ 以 下(発癌性のものは $0.01 \mathrm{mg} / \mathrm{m}^{3}$ 以下)に抑えるべきと勧告さ れている ${ }^{1)}$ 。また, 環境基本法, 水質污濁防止法などの法規 制によっても，排出量などが厳しく規制されている。

そのため, 表面処理業界においても 6 価クロム代替の動き が比較的古くからあった分野もあった。しかしながら, 実際 には, 1996 年に欧州議会から「Proposal for a European Parliament and Council Directive on end of life vihicles (車両の廃棄回収に関する指導)」の草案が提出され，その中 で「2002 年以降に販売する自動車については 6 価クロムを 使用しない」ことが謳われて以降(その後 2003 年 7 月からの 適用に延期され， 6 価クロムの使用も上限值 $2 \mathrm{~g} /$ 台に変更 された 2 ), 自動車業界を中心に 6 価クロムの使用規制の動 きが活発化してきだ)。また，国内でもこれに準じた動きが 徐々に進行している。

本稿では, 近年の 6 価クロムフリ一表面処理技術の概要に ついて，当社技術も織り交ぜながら，アルミニウム合金を中 心に，悪鉛めつき鋼板についてまで述べたい。

\section{2. クロメート処理の特性}

クロメート処理は, 主にその対象となる金属種, 形状およ び用途によって反応型，塗布型，電解型などが使い分けられ
ている。以下，アルミニウム合金用のクロメート処理を主と して，特徴を簡単に述べたい。

反応型は最も古くから用いられているもので，処理液には 6 価クロムが含まれるが, クロム酸クロメート(Yellow chromate)のように皮膜にも 6 価クロムと 3 価クロムの双方 を含むものと, リン酸クロメート(Green chromate)のよう に皮膜には 6 価クロムを含まないものがある(アルミニウム 合金のリン酸クロメート皮膜では，6価クロムはほとんど含 まれないという認識が一般的である $\left.{ }^{4)}\right)$ 。

一方，塗布型は，通常皮膜には 6 価クロムと 3 価クロムの 双方が存在している場合が多く，さらには樹脂などを混合し た複合型(いわゆる樹脂クロメート)もある。一般的には，6 価クロムを含む皮膜の方が耐食性は優れる。

また，電解クロメートはアルミニウム合金に使用されてい る例は少ないが， 6 価クロム酸浴から電解で強制的に金属ク ロムと 3 価のクロム水和酸化物を析出させる方法である。ぶ りき代替鋼板として我が国で開発されたTFS(Tin Free Steel）はその代表で, 缶用材料として多用される。また, 亜 鉛めつき鋼板に電解クロメートを施している場合もある。こ の方法は電解によって析出させるため, 反応型よりも皮膜量 制御がしやすいという利点がある。但し，初期設備投資がか かることは言うまでもない。

クロメート皮膜の防食機構は, 次のような作用によると考 えられている5)。すなわち，

(1)クロメート皮膜は 3 価クロムの酸化物・水酸化物を多く含 む難溶性高分子多核錯体が主成分であり，外的要因から素 地金属を遮蔽して保護する(バリヤー効果)。

(2)クロメート皮膜の一部は 6 価クロムを多く含む水可溶成分 から成り，皮膜に欠陥が生じるとそこで皮膜を再形成する 作用がある(自己補修効果)。

この(1)の効果はクロメート皮膜に限らず，その他の有機皮 膜などでも出しうる可能性があるが，(2)についてはクロメー 卜皮膜特有の性質であり，これがクロメート皮膜の耐食性が 優れる大きな要因であると考えられる。

クロメート皮膜の電気化学測定 (分極測定)を行ってみると, アノード側に明瞭な不働態化領域が観察され，高耐食性を裏 
付けている。図 1 は当社で測定した，A 1000 系アルミニウ 厶合金上のクロム酸クロメート皮膜の分極測定例である。

また，クロメートの自己補修効果を検証した例として，亜 鉛めつき鋼板上のクロム酸クロメート皮膜に刻まれた人工欠 陷部の腐食電流密度が経時で減少する様子を SVET (走査振 動電極法)で捉えた例を図 2 に示した ${ }^{6)}$ 。欠陥作製直後に観 られる腐食電流が 33 時間後に消失する様子が明瞭に捉えら

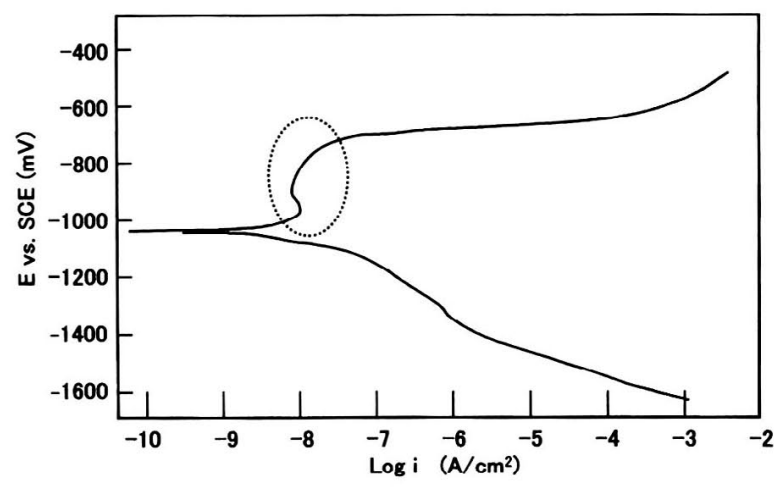

図 1 A 1000 系アルミニウム合金上のクロム酸クロメート皮膜の 分極測定例

点線丸印：不働態化領域
れており，クロメート皮膜の自己補修性の1つの証明となっ ている。

以上のことから， 6 価クロムフリーでクロメート皮膜と同 等の耐食性を持つ表面処理技術を確立するためには，(1)，(2) の機能を併せ持つものを探索・応用することが必要であると 考えられる。

\section{3. 最近の技術動向}

近年の 6 価クロムフリー，クロムフリー表面処理技術につ

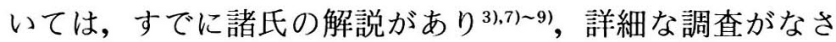
れているが，今一度全体をまとめ，さらに最近の当社技術に ついても若干の紹介をしたい。

\section{1 アルミニウム合金用表面処理}

3. 1. 1 アルミニウム業界における 6 価クロムフリー化 の状況

はじめに，アルミニウム合金を使用している業界の 6 価ク ロムフリー化の動きについて述べる。

図 3 は幾つか0業種における 6 価クロムフリー化状況をま とめたもので9)，状況は各業界によってかなり開きがあるこ とがわかる。

たとえば，アルミニウム合金製 2 ピース飲料缶ボディの化 成処理は，もともと6 価クロムフリー皮膜であるリン酸クロ
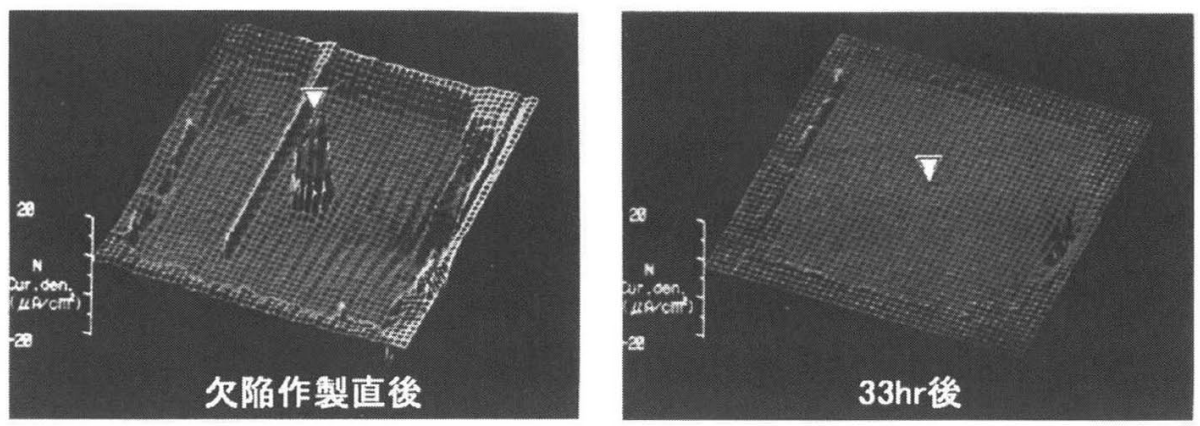

図 2 東鉛めっき鋼板上のクロム酸クロメート皮膜の自己補修性を示すSVET 測定例(6) 白 $\nabla$ が人工陷部

\begin{tabular}{|c|c|c|}
\hline 業種 & 部材 & 2000 \\
\hline \multirow{2}{*}{ 飲料缶 } & ボディ & 泟ルコニウム系 \\
\hline & エンド & $\ldots$ (ジルコニウム系) \\
\hline \multirow{3}{*}{ 自動車 } & エアコン & $\begin{array}{l}\because \because ゙ ロ ム(\text { III) 含有系 } \\
\text { ジルコニウム系、チタニウム系 }\end{array}$ \\
\hline & ロードホイール & クロム酸クロメート、リン酸クロメー上, \\
\hline & パネル & クロム酸クロメート \\
\hline \multirow{2}{*}{ 家電 } & 一般 & 一萑ルコニウム系、チタニウム系 \\
\hline & エアコン & $\begin{array}{r}\text { クロム酸クロメートートリン酸クロメート } \\
\text { 涯布型クロメート } \\
\end{array}$ \\
\hline \multirow{3}{*}{ 建材 } & 内装材 & ジルコニウム系、チタニウム系 \\
\hline & ブラインド & $\begin{array}{l}\text { クロム酸クロメート 叙布型ジルコニウム系 } \\
\text { リンン酸クロメート 塗布型チタニウム系 }\end{array}$ \\
\hline & カラーアルミ & クロム酸クロメート、リン酸クロメート \\
\hline
\end{tabular}

図 3 アルミニウム主要分野に扔けるクロムフリー化の状況 ${ }^{9}$ 
表 16 価クロムフリー反応型化成皮膜の耐食性能例 ${ }^{13)}$

\begin{tabular}{ccccc}
\hline & \multicolumn{2}{c}{ JIS-A 1000 type } & \multicolumn{2}{c}{ JIS-A 3000 type } \\
\cline { 2 - 5 } & $\begin{array}{c}\text { Coating weight } \\
\left(\mathrm{mg} / \mathrm{m}^{2}\right)\end{array}$ & $\begin{array}{c}\text { White rust } \\
\text { area }(\%)\end{array}$ & $\begin{array}{c}\text { Coating weight } \\
\left(\mathrm{mg} / \mathrm{m}^{2}\right)\end{array}$ & $\begin{array}{c}\text { White rust } \\
\text { area }(\%)\end{array}$ \\
\hline $\begin{array}{c}\text { AM-713 } \\
\text { (Yellow Chromate })\end{array}$ & $\mathrm{Cr}: 50-70$ & 0 & $\mathrm{Cr}: 80-100$ & 0 \\
\hline $\begin{array}{c}\text { Chrome free } \\
\text { Conversion Coating }\end{array}$ & $\begin{array}{c}\text { Metal A + Metal B } \\
: \text { about } 50\end{array}$ & $<5$ & $\begin{array}{c}\text { Metal A + Metal B } \\
: \text { about } 80\end{array}$ & $<5$ \\
\hline
\end{tabular}

メートが使用されていたが，かなり早期から次ステップであ る処理液の 6 価クロムフリー化(リン酸クロメートーリン酸 ジルコニウム)が進んでいることがわかる。ここでの化成処 理の要求特性は内外面の塗装密着性と裸使用されるボトム部 の耐黒変性であり，代替として使用されたリン酸ジルコニウ ムは良好な密着性が得られる皮膜量範囲はリン酸クロメート と比較するとやや狭いが, 廃水処理費用低減などの総合的性 能でリン酸クロメートとほぼ同等と考えられた。そのため, このように早期からの動きとなったものと思われる。また， 飲料缶ということから, 環境配慮イメージの重視という後押 しも手伝っていることも事実であろう。

3. 1. 2 アルミニウム合金用表面処理技術例

アルミニウムは，その表面に生じる酸化膜のバリヤー性の 高さから耐食性が良い金属に分類されているが，生じた腐食 が孔食となりやすい。クロメート処理(特にクロム酸クロ メート)は，この孔食抑制にもある程度の効果が認められて おり，アルミニウム材料の表面処理に広く利用されている理 由の一つとなっている。

クロメート処理には化成型 (反応型), 塗布型などがあるこ とは前述したが，アルミニウム分野においては，化成型であ るクロム酸クロメート, リン酸クロメートが主流である ${ }^{9}$ 。 塗布型は廃水が出ないなどのメリットがある反面，形状物へ の塗布は皮膜の均一性などに難しい面があることが背景にあ るものと思われる。

以下に，近年のアルミニウム合金に対する 6 価クロムフ リー技術について，主に反応型の化成処理に焦点をおいて述 べたい。

1） 6 価クロムフリー皮膜の文献報告例

かなりの報告事例があり，すべてを紹介することはできな いが, 代表的なものとしては, 過マンガン酸塩系化成処理 $(\mathrm{Mn})$ ，酸化セリウム化成皮膜 $(\mathrm{Ce})$ ，モリブデン系化成処理 $(\mathrm{Mo})$, リチウム塩化成皮膜 $(\mathrm{Li})$ などの報告があり ${ }^{9)}$, クロ メート皮膜に迫る耐食性を示すものもあるようである。

また，過マンガン酸塩 ${ }^{10)}$ ，セリウム系化成皮膜 ${ }^{11}$, リチウ ム系化成皮膜 ${ }^{22)}$ などでは, 孔食抑制効果があるなどの報告 も観られる。

総じて，報告例では，やはりクロムの代替としてどのよう な物質を使用すると同等の効果が得られるか，ということが 焦点になっているようである。

2 ）実用化 6 価クロムフリー表面処理技術

アルミニウム飲料缶ボディ部の化成処理を筆頭に，ジルコ ニウム系のクロムフリー化成皮膜が広く使用されてきてい る ${ }^{9)}$ 。飲料缶では化成処理の後に通常エポキシ系の塗料が塗

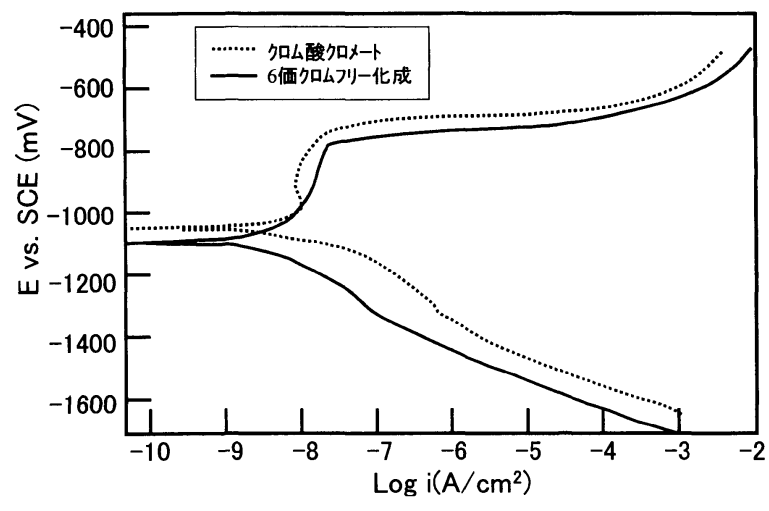

図 4 A 1000 系アルミニウム合金上の 6 価クロムフリー化成皮膜 の分極測定例

布されるため, 塗料密着性がより重視されるが，ジルコニウ 厶系皮膜は優れた密着性を示すことが知られている。また， ジルコニウムの親戚であるチタニウム系皮膜もあるが，ジル コニウム系が主流となっている9 。実際，特許調査などを 行ってみると, ジルコニウムは反応型のみならず塗布型皮膜 においても非常に多くの使用例が見られる。

また，アルミニウムフィン材では，1970年代から耐食プ ライマーとして $1 \sim 2 \mu \mathrm{m}$ 厚の樹脂単独系皮膜も使用されて いる ${ }^{9)}$

3 ）当社でのアルミニウム合金用 6 価クロムフリー表面処 理技術

反応型は，文献報告紹介の部分でも述べたが，クロム以外 の金属塩を適用する方向で開発を進めており，特に 2 種以上 の金属塩を組み合わせた処理液からの反応型化成皮膜，樹脂 と金属塩を組み合わせた有機一無機複合の反応型化成皮膜の 開発が中心となっている。特に，金属塩を組み合わせる手法 は幾つかの検討を行っている。表 1 は, 当社がアルミニウム 合金用に開発した， 2 種類の金属塩を組み合わせた反応型化 成皮膜について，裸での耐白錆性を示したものである ${ }^{13)}$ 。金 属としての付着量をクロム酸クロメートに合わせた場合の性 能比較例で, クロム酸クロメートには若干及ばないものの, A 1000 系以外の A 3000 系合金でも優れた裸耐食性を付与さ せることができている。

また，図 4 は，上記反応型化成皮膜とは別だが，同様に 2 種類の金属塩を組み合わせた反応型化成皮膜について，分極 測定を行った結果を示している(A 1000 系合金上)。クロム 酸クロメートほど明瞭な不働態化領域は観られないが，ア ノード領域での分極抵抗が大きく，クロメートに似た作用が 期待される。 


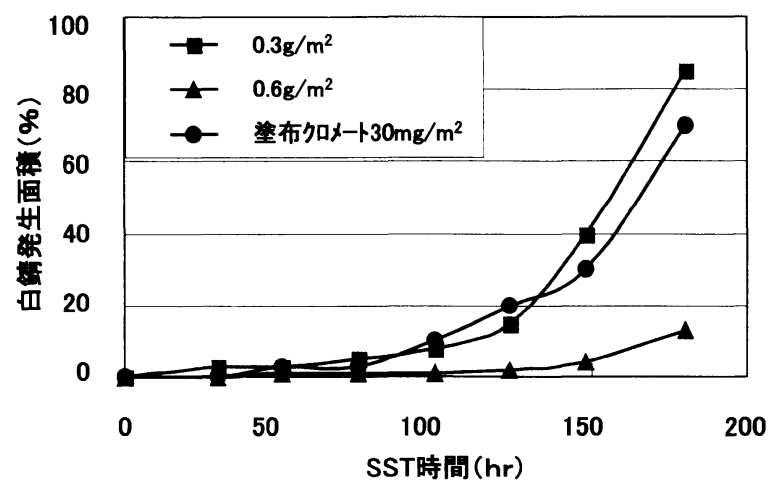

図 5 亜鉛めっき用 6 価クロムフリー複合皮膜の裸耐食性能例 素材：EG 材

一方，塗布型でも有機一無機複合系の開発が中心であり， クロメート皮膜に似た自己補修性を持つ皮膜も開発している。 添加する金属の形態・対イオンの調整などにより，このよう な特性を持つ表面処理剤が開発されつつある状況にある。

\section{2 悪鉛めっき鋼板用表面処理}

溶融亜鉛めっき鋼板, 溶融アルミ亜鉛めっき鋼板, 電気亚 鉛めつき鋼板などの亜鉛系めっき鋼板は, 家電分野, 自動車 分野, および建材分野で広く適用されており, 防錆用途, 塗 装下地などを目的にクロメート皮膜が施される。多くの場合, 一時防錆, 耐指紋樹脂コーティング下地として反応型ク口 メート, PCM(プレコートメタル)下地としては塗布型クロ メートが用いられる。

3. 2. 1 クロムフリー表面処理技術

電解クロメートは，その皮膜中に 6 価クロムを含まない 6 価クロムフリー皮膜として(前述のように, TFS は食缶用途 で多用されており，6価のクロムは含まないというのが一般 的認識である $\left.{ }^{14)}\right)$, 耐指紋樹脂コーティングの下地皮膜など で実用されている。

しかしながら, 表面処理材が溶接加工を受ける際など, さ まざまな使用環境で 6 価に酸化される可能性は否めないので， クロムをまったく含まないクロムフリー表面処理技術が求め られているのが現状である。

クロムフリー表面処理技術として，ボルト，ネジなどの小 物の防錆用途にモリブデン系化成処理が適用されている33,8) が, 耐食性レベルは従来のクロメートに比べ低く, 用途は限 定される。

3. 2. 2 当社のクロムフリー表面処理開発技術

図 5 は, 当社で開発された亜鉛系めっき鋼板用の有機・無 機複合型クロムフリー表面処理剤(有機樹脂と無機インヒビ ターを含む)を適用した場合の，付着量と耐食性の関係を表 している。 $0.3 \mathrm{~g} / \mathrm{m}^{2}$ の付着量でクロメート皮膜 $(\mathrm{Cr}=30 \mathrm{mg} /$ $\left.\mathrm{m}^{2}\right)$ とほぼ同等の耐食性を示す。

耐指紋鋼板は, 家電部材に成型加工される際, 溶接加工を 受ける場合が多く, また, OA 機器に適用される場合など, 電磁波シールド性，アース性などが要求される。このため, 皮膜にある程度の導電性を有することが望まれる。耐食性と 導電性は何れも皮膜厚に依存する性能アイテムであり，互い に相反する傾向である。図 6 は, 当社で開発されたクロムフ

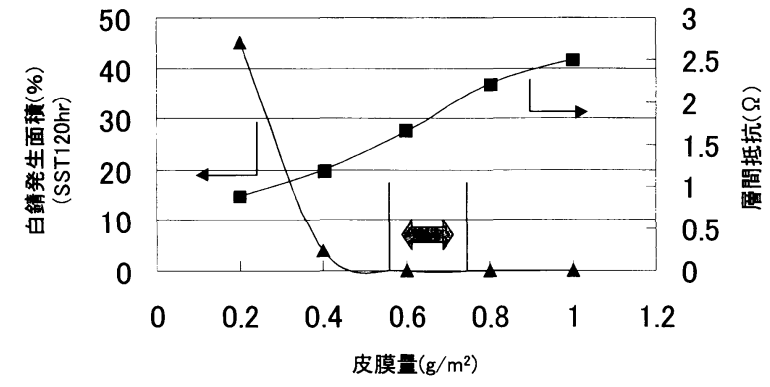

図 6 覀鉛めつき用耐指紋樹脂皮膜( 1 コート型)の皮膜量と耐食 性・導電性の関係

リ一耐指紋樹脂皮膜 ( 1 コートタイプ) の皮膜量と耐食性, 導 電性の関係を表したもので，0.6〜 $0.8 \mathrm{~g} / \mathrm{m}^{2}$ に両立領域があ る。

PCM 下地として無機系皮膜を中心に検討しており，クロ メートにほぼ近い耐食性と密着性を付与することが確認され ているが，組み合わせるクロムフリープライマーの影響が大 きく, システムとして開発する必要がある。また, 実環境に より忠実なサイクル腐食促進試験で評価していく必要がある。

\section{4.まとめ}

最近の 6 価クロムフリー技術について述べてきた。耐食性 という点では, 条件にもよるが, クロメート皮膜に迫る技術 も出始めている。しかし, 文中でも述べたように, クロメー 卜処理は末だ広く用いられており, 地球環境保護への貢献と いう点からもさらなる 6 価クロムフリー代替技術の開発を進 め，これを社会に広めていくことが我々表面処理薬剤開発者 の使命であると考えている。

(2001-12-13 受理)

\section{文献}

1 ）労働基準実務研究会編; 化学物質労働安全衛生法規制便覧, p. 9525 (第一法規, 1993)

2 ) Community legislation in force ; [Directive 2000/53/EC of the European Parliament and of Council of 18 September 2000 on end-of life vehicles ], Official Journal L 269, p 34, 21/ $10 / 2000$.

3 ）山崎龍一; 防錆管理, 43, 389 (1999)

4 ）田中茂夫, 青木智幸, 吉田昌之; 日本パーカライジング技報, 1 , 68 (1988)

5 ）須田 新, 荻野睦雄, 田中成夫 ; 鉄と鋼, 77, 1042（1991）

6 ) 須田 新, 浅利満頼; 材料と環境, 46, 99 (1997)

7 ）青江徹博；表面技術, 49, 221 （1998）

8 ）前田重義；防錆管理, 43, 348 (1999)

9 ）森田良治, 金子秀昭, 大下賢一郎；軽金属, 50, 560 (2000)

10) I. Danilidis, J. M. Sykes, G. M. Scamans ; Surface Engineering, 15, 401 (1999)

11) F. Mansfeld, Y. Wang, S. H. Lin ; Electrochemical Society Proceedings, 95-15, 308 (1996)

12）田中慎一, 磯部保明, 日根文男；防食技術, 39, 425 (1990)

13）軽部健志，相島敏行，中田和也；日本パーカライジング技報, 14, 68 (2001)

14）前田重義；金属表面技術，31，402（1980） 